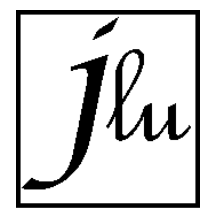

https://jurnal.univpgripalembang.ac.id/index.php/luminous
Jurnal Luminous 02 (2) (2021) 24-29

Riset IImiah Pendidikan Fisika

Vol. 2 No. 2 (2021) hal 24
E-ISSN 2715-6990

P-ISSN 2715-9582

082021

\title{
ANALISIS KOMPETENSI PEDAGOGIK GURU IPA SMP KOTA TERNATE DALAM PEMBELAJARAN LITERASI SAINS
}

\author{
Nasrun Balulu ${ }^{1 \star}$, Masrifah $^{1}$, La Eki ${ }^{1}$ \\ ${ }^{1}$ Program studi Pendidikan Fisika, Fakultas Keguruan dan IImu Pendidikan, Universitas Khairun Ternate \\ Jalan Bandara Baabullah Kota Ternate, 97728, Indonesia \\ E-mail: nasrunbalulu@gmail.com
}

Received: 3107 2021. Accepted: 0208 2021. Published: 082021

\begin{abstract}
Abstrak
Penelitian ini bertujuan untuk mengetahui kompetensi pedagogik guru IPA dalam pembelajaran literasi sains. Jenis penelitian ini adalah penelitian deskriptif kualitatif. Penelitian ini dilakukan di SMPN 2, SMPN 6, dan SMPN 7 kota Ternate dengan melibatkan subjek penelitian sebanyak 3 guru fisika. Data yang diperoleh selanjutnya dianalisis secara deskriptif untuk melihat kompetensi guru fisika pada pembelajaran literasi sains. Hasil penelitian menunjukkan bahwa kompetensi pedagogik subyek G01 pada indikator 1,2,3,4, 10 tergolong sangat baik dan untuk indikator 5,6,7,8,9 berada pada kriteria baik. Sedangkan kompetensi pedagogik subyek G02 indikator 1,3,4,5,6,7,8,9,10 menunjukkan kriteria sangat baik dan indikator 2 kriteria baik. Selanjutnya kompetensi pedagogik subyek G03 untuk indikator 1,4,5,6,7,8,9,10 berada pada kriteria sangat baik dan indikator 2,3 kriteria baik. Hasil wawancara menunjukkan bahwa subyek menerima kebijakan pemerintah terkait pengembangan kurikulum serta implementasinya dalam pembelajaran literasi sains yang sesuai tuntutan kurikulum K13. Sehingga dapat disimpulkan bahwa semua subyek memenuhi indikator pada kompetensi pedagogik.
\end{abstract}

Kata Kunci: kompetensi pedagogik, literasi sain

(C) 20XX Pendidikan Fisika FKIP UPGRI Palembang

\section{PENDAHULUAN}

Kehidupan masyarakat saat ini telah berkembang seiring pesatnya perkembangan sains dan teknologi. Hal ini menuntut manusia untuk semakin bekerja keras menyesuaikan diri dalam segala aspek kehidupan, salah satunya adalah aspek pendidikan. Pendidikan diharapkan berperan sebagai jembatan yang akan menghubungkan individu dengan lingkungannya ditengah-tengah era globalisasi yang semakin berkembang, sehingga individu mampu berperan sebagai sumber daya manusia yang berkualitas (Sumartati, 2009) dalam (Dinata,dkk, 2018).
Dalam dunia yang dipenuhi dengan produk-produk kerja ilmiah, literasi sains menjadi suatu keharusan bagi setiap orang. Literasi sains sangatlah penting hal ini disebabkan karena warga negara dihadapkan pada pertanyaan-pertanyaan dalam kehidupannya yang memerlukan informasi ilmiah dan cara berpikir ilmiah untuk mengambil keputusan dan kepentingan orang banyak yang perlu diinformasikan seperti, udara, air dan hutan (Zuriyani, 2011) dalam (Dinata, dkk, 2018).

Hasil pembelajaran sains di Indonesia pada saat ini belum sesuai dengan harapan kurikulum 2013, karena belum mampu membentuk 
manusia Indonesia yang lebih kreatif dalam menghadapi masa depan.

Peranan guru sangat signifikan dalam usaha peningkatan mutu pendidikan. Untuk itu, guru dituntut untuk memiliki kompetensi dalam menyelenggarakan proses pembelajaran dengan sebaik-baiknya (Kurniasih dan Sani, 2015). Kompetensi guru merupakan seperangkat pengetahuan, keterampilan, dan perilaku yang harus dimiliki, dihayati, dikuasai dan diwujudkan oleh guru dalam melaksanakan tugas keprofesionalannya. Kompetensi yang harus dimiliki pendidik (guru) yang terdapat dalam UU No. 14 Tahun 2005 tentang guru dan dosen menyatakan bahwa kompetensi guru meliputi kompetensi pedagogik, kompetensi kepribadian, kompetensi sosial, dan kompetensi profesional (Sopiatin, 2010). Kompetensi tersebut harus terus dikembangkan oleh guru agar senantiasa mampu menciptakan pembelajaran yang efektif.

$\mathrm{Hal}$ ini sejalan dengan hasil observasi disekolah SMPN 7, SMPN 6, dan SMPN 2 Kota Ternate menunjukkan bahwa masih terdapat siswa yang memiliki nilai rendah dibawah KKM sebesar $10 \%$ walaupun sudah dilakukan remedial dan pengayaan. Berdasarkan hasil wawancara dengan guru mata pelajaran fisika peneliti mendapati bahwa pembelajaran literasi sudah diterapkan selama 5 tahun. Pengembangan perangkat pembelajaran sudah berbasis literasi, proses pembelajaran guru lebih banyak menggunakan metode ceramah dan penggunaan model pembelajaran belum efektif sehingga berakibat kurangnya siswa dalam belajar literasi khususnya literasi sains.

Berdasarkan permasalahan dan kenyataan yang telah diuraikan, maka dilakukan penilitian dengan judul "Analisis Kompetensi Pedagogik dan Profesional Guru IPA SMP Kota Ternate Dalam Pembelajaran Literasi Sains"

\section{METODE}

Penelitian ini adalah penelitian deskriptif dengan pendekatan kualitatif untuk menggali proses literasi sains guru IPA SMP dalam pembelajaran literasi sains fisika pada mata pelajaran listrik dinamis. Prabowo (2011) menyatakan penelitian kualitatif pada hakikatnya adalah mengamati manusia dalam lingkungan hidupnya, berinteraksi dengan mereka, berusaha memahami bahasa dan tafsiran mereka tentang dunia sekitarnya.

Penentuan subjek dalam penelitian kualitatif tidak didasarkan dalam perhitungan statistik. Subjek yang dipilih berfungsi untuk mendapatkan informasi yang maksimum, bukan untuk digeneralisasikan (Guba \& Lincoln, 1985). Subjek yang terpilih diberi kode agar memudahkan peneliti, seperti yang ditunjukan pada tabel 1 .

Tabel 1. Pengkodean Calon Subjek

\begin{tabular}{lcc}
\hline Kelompok Literasi Sains & $\begin{array}{c}\text { Inisial } \\
\text { Subjek }\end{array}$ & Kode \\
\hline $\begin{array}{l}\text { Subjek literasi sains guru } \\
\text { SMPN 2 Kota Ternate }\end{array}$ & RM & G 01 \\
\hline $\begin{array}{l}\text { Subjek literasi sains guru } \\
\text { SMPN 6 Kota Ternate }\end{array}$ & RB & G 02 \\
\hline $\begin{array}{l}\text { Subjek literasi sains guru } \\
\text { SMPN 7 Kota Ternate }\end{array}$ & WM & G 03 \\
\hline
\end{tabular}

Teknik Pengumpulan data dilakukan dengan observasi, pemberian tes literasi sains, wawancara, trianggulasi dan dokumentasi terhadap seluruh aktivitas subjek penelitian. Adapun aktivitas yang diobservasi dan didokumentasi adalah seluruh kegiatan pengambilan data sehingga diperoleh data pembelajaran secara komprehensif.

\section{HASIL DAN PEMBAHASAN}

Berdasarkan undang-undang no. 14 tahun 2005 tentang guru dan dosen dijelaskan bahwa kompetensi pedagogi merupakan kemampuan seorang guru dalam mengelola proses pembelajaran yang berhubungan dengan peserta didik, meliputi pemahaman wawasan atau landasan kependidikan, pemahaman terhadap peserta didik, pengembangan kurikulum atau silabus, perancangan pembelajaran, pelaksanaan pembelajaran yang mendidik dan dialogis, pemanfaatan teknologi pembelajaran, evaluasi hasil belajar, dan pengembangan peserta didik 
untuk mengaktualisasikan berbagai potensi yang dimilikinya. Berikut diuraikan hasil penelitian kompetensi pedagogik guru IPA pada pembelajaran literasi sains pada setiap indikatornya.

1. Memahami karakteristik peserta didik dari aspek fisik, moral, spiritual, sosial, kultural emosional, dan intelektual.

Kompetensi pedagogik pertama yang harus dikuasai oleh guru adalah memahami karakteristik peserta didik. guru harus memahami prinsip-prinsip perkembangan kepribadian peserta didik agar dapat mengaktualisasikan berbagai potensi yang dimiliki siswa. Hal ini sejalan dengan penelitian yang dilakukan oleh (Evanita, 2013) menunjukkan pemenuhan kompetensi pedagogik indikator 1, 2, 3, 4, 7, 8, dan 9 menunjukkan kriteria sangat baik dan pemenuhan indikator 5,6 , dan 10 menunjukkan kriteria baik.

\section{a. Guru G01}

Berdasarkan hasil penelitian menunjukkan guru G01 telah memahami karakteristik peserta didik dapat dikatakan terpenuhi dengan sangat baik. Hal itu dapat dilihat dari keempat item yang menunjukkan bahwa pemenuhan indikator kompetensi pedagogik guru dalam kriteria sangat baik.

b. Guru G02

Berdasarkan hasil penelitian menunjukkan guru G02 sudah memahami karakteristik peserta didik dapat dikatakan terpenuhi dengan sangat baik. Hal itu dapat dilihat dari keempat item yang menunjukkan bahwa pemenuhan indikator kompetensi pedagogik guru dalam kriteria sangat baik.

c. Guru G03

Berdasarkan hasil penelitian menunjukkan guru G03 dapat memahami karakteristik peserta didik dapat dikatakan terpenuhi dengan sangat baik. Hal itu dapat dilihat dari keempat item yang menunjukkan bahwa pemenuhan indikator kompetensi pedagogik guru dalam kriteria sangat baik.

2. Menguasai teori belajar dan prinsip-prinsip pembelajaran yang mendidik.
Guru harus memiliki pemahaman akan sifat, ciri anak didik dan perkembangannya, mengerti beberapa konsep pendidikan yang berguna untuk membantu siswa, menguasai beberapa metode mengajar yang sesuai dengan materi pelajaran dan perkembangan siswa, menguasai sistem evaluasi yang tepat dan baik (Sanaky, 2005).

a. Guru G01

Berdasarkan hasil penelitian menunjukkan guru G01 telah memahami teori belajar dan prinsip-prinsip pembelajaran yang mendidik dapat dikatakan terpenuhi dengan sangat baik. Hal itu dapat dilihat dari kedua item yang menunjukkan bahwa pemenuhan indikator kompetensi pedagogik guru dalam kriteria sangat baik.

b. Guru G02

Berdasarkan hasil penelitian menunjukkan guru G02 sudah memahami teori belajar dan prinsip-prinsip pembelajaran yang mendidik dapat dikatakan terpenuhi dengan baik. Hal itu dapat dilihat dari kedua item yang menunjukkan bahwa pemenuhan indikator kompetensi pedagogik guru dalam kriteria baik.

\section{c. Guru G03}

Berdasarkan hasil penelitian menunjukkan guru G03 dapat memahami teori belajar dan prinsip-prinsip pembelajaran yang mendidik dapat dikatakan terpenuhi dengan baik. Hal itu dapat dilihat dari kedua item yang menunjukkan bahwa pemenuhan indikator kompetensi pedagogik guru dalam kriteria baik.

3. Mengembangkan Kurikulum Yang Terkait Dengan Mata Pelajaran Yang Diampu.

Kompetensi mengembangkan kurikulum dapat terlihat dari kemampuan guru untuk menentukan tujuan pembelajaran serta memilih materi sesuai dengan pendekatan dan karakter peserta didik (PP no. 69 2013).

a. Guru G01

Berdasarkan hasil penelitian menunjukkan guru G01 telah memahami pengembangan kurikulum yang terkait dengan mata pelajaran yang diampu dapat dikatakan terpenuhi dengan sangat baik. Hal itu dapat dilihat dari keenam item yang menunjukkan bahwa pemenuhan indikator 
kompetensi pedagogik guru dalam kriteria sangat baik.

b. Guru G02

Berdasarkan hasil penelitian menunjukkan guru G02 sudah memahami pengembangan kurikulum yang terkait dengan mata pelajaran yang diampu dapat dikatakan terpenuhi dengan sangat baik. Hal itu dapat dilihat dari keenam item yang menunjukkan bahwa pemenuhan indikator kompetensi pedagogik guru dalam kriteria sangat baik.

c. Guru G03

Berdasarkan hasil penelitian menunjukkan guru G03 dapat memahami pengembangan kurikulum yang terkait dengan mata pelajaran yang diampu dapat dikatakan terpenuhi dengan baik. Hal itu dapat dilihat dari keenam item yang menunjukkan bahwa pemenuhan indikator kompetensi pedagogik guru dalam kriteria baik.

4. Menyelenggarakan Pembelajaran Yang Mendidik.

a. Guru G01

Berdasarkan hasil penelitian menunjukkan guru G01 telah memahami pembelajaran yang mendidik dapat dikatakan terpenuhi dengan sangat baik. Hal itu dapat dilihat dari keenam item yang menunjukkan bahwa pemenuhan indikator kompetensi pedagogik guru dalam kriteria sangat baik.

b. Guru G02

Berdasarkan hasil penelitian menunjukkan guru G02 sudah memahami pembelajaran yang mendidik dapat dikatakan terpenuhi dengan sangat baik. Hal itu dapat dilihat dari keenam item yang menunjukkan bahwa pemenuhan indikator kompetensi pedagogik guru dalam kriteria sangat baik.

\section{c. Guru G03}

Berdasarkan hasil penelitian menunjukkan guru G03 dapat memahami pembelajaran yang mendidik dapat dikatakan terpenuhi dengan sangat baik. Hal itu dapat dilihat dari keempat item yang menunjukkan bahwa pemenuhan indikator kompetensi pedagogik guru dalam kriteria sangat baik.
5. Memanfaatkan Teknologi Informasi dan Komunikasi Untuk Pembelajaran.

\section{a. Guru G01}

Berdasarkan hasil penelitian menunjukkan guru G01 telah memahami teknologi informasi dan komunikasi untuk pembelajaran dapat dikatakan terpenuhi dengan baik. Hal itu dapat dilihat dari kesatu item yang menunjukkan bahwa pemenuhan indikator kompetensi pedagogik guru dalam kriteria baik.

b. Guru G02

Berdasarkan hasil penelitian menunjukkan guru G02 sudah memahami teknologi informasi dan komunikasi untuk pembelajaran dapat dikatakan terpenuhi dengan sangat baik. Hal itu dapat dilihat dari kesatu item yang menunjukkan bahwa pemenuhan indikator kompetensi pedagogik guru dalam kriteria sangat baik.

\section{c. Guru G03}

Berdasarkan hasil penelitian menunjukkan guru G03 dapat memahami teknologi informasi dan komunikasi untuk pembelajaran dapat dikatakan terpenuhi dengan sangat baik. Hal itu dapat dilihat dari kesatu item yang menunjukkan bahwa pemenuhan indikator kompetensi pedagogik guru dalam kriteria sangat baik.

6. Memfasilitasi Pengembangan Potensi Peserta Didik Untuk Mengaktualisasikan Berbagai Potensi Yang Dimiliki.

\section{a. Guru G01}

Berdasarkan hasil penelitian menunjukkan guru G01 telah memahami pengembangan potensi peserta didik untuk mengaktualisasikan berbagai potensi yang dimiliki dapat dikatakan terpenuhi dengan baik. Hal itu dapat dilihat dari kedua item yang menunjukkan bahwa pemenuhan indikator kompetensi pedagogik guru dalam kriteria baik.

\section{b. Guru G02}

Berdasarkan hasil penelitian menunjukkan guru G02 sudah memahami pengembangan potensi peserta didik untuk mengaktualisasikan berbagai potensi yang dimiliki dapat dikatakan terpenuhi dengan sangat baik. Hal itu dapat dilihat dari kedua item yang menunjukkan bahwa 
pemenuhan indikator kompetensi pedagogik guru dalam kriteria sangat baik.

c. Guru G03

Berdasarkan hasil penelitian menunjukkan guru G03 dapat memahami pengembangan potensi peserta didik untuk mengaktualisasikan berbagai potensi yang dimiliki dapat dikatakan terpenuhi dengan sangat baik. Hal itu dapat dilihat dari kedua item yang menunjukkan bahwa pemenuhan indikator kompetensi pedagogik guru dalam kriteria sangat baik.

7. Berkomunikasi Secara Efektif, Empatik, dan Santun Dengan Peserta Didik.

a. Guru G01

Berdasarkan hasil penelitian menunjukkan guru G01 telah memahami berkomunikasi secara efektif, empatik, dan santun dengan peserta didik dapat dikatakan terpenuhi dengan baik. Hal itu dapat dilihat dari kedua item yang menunjukkan bahwa pemenuhan indikator kompetensi pedagogik guru dalam kriteria baik.

b. Guru G02

Berdasarkan hasil penelitian menunjukkan guru G02 sudah memahami berkomunikasi secara efektif, empatik, dan santun dengan peserta didik dapat dikatakan terpenuhi dengan sangat baik. Hal itu dapat dilihat dari kedua item yang menunjukkan bahwa pemenuhan indikator kompetensi pedagogik guru dalam kriteria sangat baik.

c. Guru G03

Berdasarkan hasil penelitian menunjukkan guru G03 dapat memahami berkomunikasi secara efektif, empatik, dan santun dengan peserta didik dapat dikatakan terpenuhi dengan sangat baik. Hal itu dapat dilihat dari kedua item yang menunjukkan bahwa pemenuhan indikator kompetensi pedagogik guru dalam kriteria sangat baik.

8. Menyelenggarakan Penilaian dan Evaluasi Proses Hasil Belajar.

a. Guru G01

Berdasarkan hasil penelitian menunjukkan guru G01 telah memahami penilaian dan evaluasi proses hasil belajar dapat dikatakan terpenuhi dengan baik. Hal itu dapat dilihat dari ketujuh item yang menunjukkan bahwa pemenuhan indikator kompetensi pedagogik guru dalam kriteria baik.

b. Guru G02

Berdasarkan hasil penelitian menunjukkan guru G02 sudah memahami penilaian dan evaluasi proses hasil belajar dapat dikatakan terpenuhi dengan sangat baik. Hal itu dapat dilihat dari ketujuh item yang menunjukkan bahwa pemenuhan indikator kompetensi pedagogik guru dalam kriteria sangat baik.

c. Guru G03

Berdasarkan hasil penelitian menunjukkan guru G03 dapat memahami penilaian dan evaluasi proses hasil belajar dapat dikatakan terpenuhi dengan sangat baik. Hal itu dapat dilihat dari ketujuh item yang menunjukkan bahwa pemenuhan indikator kompetensi pedagogik guru dalam kriteria sangat baik.

9. Memanfaatkan Hasil Penilaian dan Evaluasi Untuk Kepentingan Pembelajaran.

a. Guru G01

Berdasarkan hasil penelitian menunjukkan guru G01 telah memahami hasil penilaian dan evaluasi untuk kepentingan pembelajaran dapat dikatakan terpenuhi dengan baik. Hal itu dapat dilihat dari keempat item yang menunjukkan bahwa pemenuhan indikator kompetensi pedagogik guru dalam kriteria baik.

\section{b. Guru G02}

Berdasarkan hasil penelitian menunjukkan guru G02 sudah memahami hasil penilaian dan evaluasi untuk kepentingan pembelajaran dapat dikatakan terpenuhi dengan sangat baik. Hal itu dapat dilihat dari keempat item yang menunjukkan bahwa pemenuhan indikator kompetensi pedagogik guru dalam kriteria sangat baik.

\section{c. Guru G03}

Berdasarkan hasil penelitian menunjukkan guru G03 dapat memahami hasil penilaian dan evaluasi untuk kepentingan pembelajaran dapat dikatakan terpenuhi dengan sangat baik. Hal itu dapat dilihat dari keempat item yang menunjukkan bahwa pemenuhan indikator kompetensi pedagogik guru dalam kriteria sangat baik.

10.Melakukan Tindakan Reflektif Untuk Peningkatan Kualitas Pembelajaran. 


\section{a. Guru G01}

Berdasarkan hasil penelitian menunjukkan guru G01 telah memahami tindakan reflektif untuk peningkatan kualitas pembelajaran dapat dikatakan terpenuhi dengan sangat baik. Hal itu dapat dilihat dari ketiga item yang menunjukkan bahwa pemenuhan indikator kompetensi pedagogik guru dalam kriteria sangat baik.

b. Guru G02

Berdasarkan hasil penelitian menunjukkan guru G02 sudah memahami hasil tindakan reflektif untuk peningkatan kualitas pembelajaran dapat dikatakan terpenuhi dengan sangat baik. Hal itu dapat dilihat dari ketiga item yang menunjukkan bahwa pemenuhan indikator kompetensi pedagogik guru dalam kriteria sangat baik.

c. Guru G03

Berdasarkan hasil penelitian menunjukkan guru G03 dapat memahami hasil tindakan reflektif untuk peningkatan kualitas pembelajaran dapat dikatakan terpenuhi dengan baik. Hal itu dapat dilihat dari ketiga item yang menunjukkan bahwa pemenuhan indikator kompetensi pedagogik guru dalam kriteria baik.

\section{SIMPULAN}

Kompetensi pedagogik guru G01, guru G02, dan guru G03 Kota Ternate sesuai dengan tuntutan kurikulum 2013. Guru IPA yang mengajar di SMP menerapkan 10 indikator kompetensi pedagogik menurut Permendiknas Nomor 16 tahun 2007 dalam proses mengajar. Hasil penelitian menunjukkan bahwa pemenuhan kompetensi pedagogik indikator 1, 2, 3, 4, 7, 8, dan 9 menunjukkan kriteria sangat baik dan pemenuhan indikator 5,6 , dan 10 menunjukkan kriteria baik. Dengan kompetensi pedagogik baik maka guru akan lebih mudah mengimplementasikan kurikulum 2013.

\section{DAFTAR PUSTAKA}

Astutik, S., (2019). Model Pembelajaran Collaborative Creativity (CC) Untuk Meningkatkan Efektif Kolaboratif IImiah dan Kreativitas IImiah Siswa. Tidak dipublikasikan.

Dinata, A.N. \& Yusuf, H. A. \& Amprasto. (2018). Pengaruh Field Trip Terhadap Kemampuan Literasi Sains dan Sikap Terhadap Sains Siswa SMA Pada Materi Ekosistem. Indonesian Journal of Biology Education 1(1): 8-13.

Depdiknas. (2006). Kurikulum Tingkat Satuan Pendidikan Mata Pelajaran IPA SMP/MTs. Jakarta.

Faisal, Sanapiah. 1990. Penelitian Kualitatif (dasar-dasar dan aplikası). Malang: Ya3 Malang.

Peraturan Menteri Negara Pendayagunaan Aparatur Negara dan Reformasi Birokrasi Nomor 16 Tahun 2009 tentang Jabatan Fungsional Guru dan Angka Kreditnya.

Peraturan Pemerintah RI No. 16 Tahun 2007 tentang standar Kualifikasi Akademik dan Kompetensi Guru.

Prabowo. (2011). Metodologi Penelitian (Sains dan Pendidikan Sains). Penerbit Unesa University Press. Surabaya.

Sopiatin, Popi. Manajemen Belajar Berbasis Kepuasan Siswa. Bogor: Ghalia Indonesia, 2010. 